\title{
Evaluating Lateral Spreading Using Newmark Method Based on Liquefaction Triggering
}

\author{
Yanxin Yang $\mathbb{D},{ }^{1}$ Junhua Chen $\mathbb{D},{ }^{1}$ Zhenqiang Zhang, ${ }^{2}$ and Jianlin $\mathrm{Ma} \mathbb{D}^{3}$ \\ ${ }^{1}$ School of Architecture and Transportation Engineering, Guilin University of Electronic Technology, Guilin, Guangxi 541004, \\ China \\ ${ }^{2}$ Henan Xupingnan Expressway Co. Ltd., Zhengzhou, Henan 450003, China \\ ${ }^{3}$ School of Civil Engineering, Southwest Jiaotong University, Chengdu, Sichuan 610031, China
}

Correspondence should be addressed to Yanxin Yang; actor99yyx@my.swjtu.edu.cn and Junhua Chen; jhchan@126.com

Received 3 January 2020; Revised 2 November 2020; Accepted 12 December 2020; Published 24 December 2020

Academic Editor: Emanuele Brunesi

Copyright (c) 2020 Yanxin Yang et al. This is an open access article distributed under the Creative Commons Attribution License, which permits unrestricted use, distribution, and reproduction in any medium, provided the original work is properly cited.

\begin{abstract}
The prediction of liquefaction-induced lateral spreading is an important geotechnical engineering problem. In this paper, a simplified prediction method based upon Newmark sliding block analysis was proposed to predict the liquefaction-induced lateral spreading. The acceleration time history beneath the liquefied soil (starting from the triggering time of liquefaction) and the postliquefaction yield acceleration corresponding with the residual shear strength of liquefiable soil were used in the Newmark sliding block analysis. One-dimensional effective stress analysis was conducted to obtain the motion beneath the liquefied soil and the liquefaction time. Limit equilibrium analysis was employed to determine the postliquefaction yield acceleration using the residual shear strength of liquefied soil, which correlated with the equivalent clean sand SPT blow count of the liquefied sand. This method was evaluated against five well-documented case histories and the predicted displacements of lateral spreading were subsequently compared with the observed displacements. In addition, the lateral spreading predicted by the rigorous Newmark sliding block method and numerical difference analysis was presented. Based on the statistical analysis of the displacement ratios, it suggested that the method proposed in this paper identified the triggering time of liquefaction and provided a reasonable prediction of the liquefaction-induced lateral spreading with an RMSE (root mean square error) of 0.63, a standard deviation of 0.40 , and a CV (coefficient of variance) of 0.60 , respectively.
\end{abstract}

\section{Introduction}

The lateral spreading is the earthquake-induced horizontal displacement of the gently sloping ground or the level ground underlain by liquefiable soil. Recent earthquakes showed that the lateral spreading has caused severe damage, so the displacement of the liquefaction-induced lateral spreading needed to be assessed for seismic mitigation. Existing procedures, such as empirical methods, numerical methods, and probabilistic methods have been used for predicting lateral spreading. Regarding the empirical methods, the soil properties, seismic motions, and the site geometry of the case histories were used to develop regression models by many researchers [1-7]. Considering the effects of seismological parameters, geotechnical parameters of soil, and site geometry on the lateral spreading, the probabilistic methods [8-10] were established based on the statistical analysis of the case histories. Various types of constitutive models of liquefied soil were adopted in the numerical methods [11-15] to simulate the problems involving the lateral spreading. In a summary, the existing prediction procedures have been used to address some aspects of liquefaction or liquefaction-induced lateral spreading, while the inherent limitations of these methods, the uncertainties of the soil profile, the variability in liquefiable soil, and the complexity of lateral spreading increase the research on proposing a new prediction method.

The mechanism of liquefaction-induced lateral spreading has been investigated and recognized. For the sites subject to liquefaction-induced lateral spreading, once the 
liquefaction was triggered (i.e., the excess pore water pressure built up and the effective stress was approaching zero), the intact soil above the liquefied soil moved laterally as the combined driving force (i.e., the static force and seismic force) was greater than the residual shear strength, which was the minimum strength retained by the liquefied soil. The permanent displacement of the intact soil began to accumulate and was induced by the motion beneath the liquefied soil. The residual shear strength of the liquefied soil was greater than the static force but smaller than the combined driving force (i.e., the static and seismic force) during the shaking. When the shaking ceased, the movement of the intact soil stopped.

Based on the mentioned-above mechanism of liquefaction-induced lateral spreading, the Newmark sliding block method [16] is capable of modeling the displacement. Furthermore, the residual shear strength is corresponding to the minimum shear strength of the soil experiencing lateral spreading due to the earthquake loading, so the residual shear strength can determine the postliquefaction stability of the level grounds. Considering that the intact soil will move along the sliding surface developed within the liquefied soil, the motion beneath the liquefied soil will eventually induce the displacement of the overburden soil. Therefore, incorporating the motion beneath the liquefied soil that starts from the triggering time of liquefaction is more consistent with the mechanism of liquefaction-induced lateral spreading. At the same time, the displacement of lateral spreading was associated with the nonlinear stress-strain response of liquefied soil and the liquefaction effect. To make the prediction procedure to be facilitated with engineers, a simplified method is proposed that considered the influence of the nonlinear soil behavior of the liquefiable soil and triggering of liquefaction on the accumulation of displacement. Given these factors, the proposed method will manifest the effect of liquefaction on the lateral spreading and the mechanism of lateral spreading in a clear and simple manner.

In the paper, a simplified prediction method was proposed based upon Newmark sliding block analysis in terms of nonlinear soil response of the liquefied soil and triggering time of liquefaction. The triggering time of liquefaction of the site and the time histories beneath the liquefiable soil were obtained using one-dimensional effective stress analysis. The postliquefaction yield acceleration was calculated using limit equilibrium analysis based on the residual shear strength of the liquefied soil. Though CPT (cone penetration test) represents the soil profile with continuous data rather than the intermittent one like SPT and it has better repeatability compared to that of SPT, the specific value of SPT for the layer of liquefiable soil can represent the overall liquefaction susceptibility and it can be converted from CPT values. To estimate the residual shear strength of liquefied soil, the estimation method that correlated the residual shear stress ratio (the residual shear strength to the effective overburden stress) to the equivalent clean sand SPT blow count of liquefied sand was used.

Newmark sliding block method was then used to predict lateral spreading with the motion beneath the liquefiable soil starting from the triggering time of liquefaction to the end of shaking and the postliquefaction yield acceleration corresponding with the residual shear strength of liquefied soil. Furthermore, to evaluate the accuracy of the proposed method proposed in this paper, five well-documented case histories were analyzed with the proposed simplified method. The comparison between the lateral spreading predicted by the other three methods and the observed displacements for the same case histories was made and presented in the paper.

\section{One-Dimensional Effective Stress Site Response Analysis}

The local geologic condition of the liquefiable site will have a significant effect on the site response induced by the propagation of seismic waves. The site response can be analyzed using the equivalent linear and nonlinear analysis methods. The equivalent linear approach approximates the nonlinear response of soil using the strain-compatible modulus degradation and damping curves. One of the representative equivalent linear approaches is SHAKE 91 [17], which has been widely used and referenced in geotechnical engineering. In this method, the soil deposits are horizontally layered, and the shear waves are assumed to propagate vertically from a half-space (i.e., bedrock) to the top of the soil profile. As the soil is modeled as viscoelastic, the variation of shear modulus and damping ratio are specified with the shear strain to represent the nonlinear behavior of the soil. An iterative procedure of the equivalent linear analysis is used to calculate the stiffness and damping of the soil deposits. Once the calculated stiffness and damping are compatible with the effective strain induced by the seismic loading, the dynamic response of the site will be obtained. It is clear that the equivalent linear approach has some limitations. The soil stiffness and damping are constants during the final iteration, and it can only capture the small-strain behavior of the soil.

In the cases that the soil is subject to strong seismic waves or the soil liquefies due to the strong motions, the strain of the soil is larger and nonlinear; thus, nonlinear analysis shall be used to represent the variations of shear modulus and damping ratio. Nonlinear analysis computer codes in terms of effective stress have been developed to simulate the site response, such as acceleration time history, pore water pressure generation, and strain time history. In the timedomain nonlinear analysis, the soil stiffness is updated at each time-step.

The computer code DESRA-2 [18] assumed the soil as a lumped mass, and the soil layer was discretized into lumped masses with multiple degrees of freedom. A simple hyperbolic constitutive model (i.e., backbone curve) with Masing criteria was employed to capture the nonlinear feature of the soil. Fully Rayleigh damping (i.e., viscous damping) was incorporated for solving the shear wave equation. The computer code D-Mod 2000 [19] modified the DESRA and used a Modified Konder-Zelasko [20] constitutive model.

In the Konder-Zelasko model [21], the hysteretic behavior of soil is following the Masing unload-reload rules. 
Equation (1) shows the strain-stress relationship of the liquefiable sand under the initial loading:

$$
\tau=f(\gamma)=\frac{G_{m o} \gamma}{1+G_{m o} / \tau_{m o}},
$$

where $\tau$ is the given shear stress, $\gamma$ is the given shear strain, $G_{m o}$ is the initial shear modulus, and $\tau_{m o}$ is the initial shear strength of the soil.

The Modified Konder-Zelasko model includes two dimensionless parameters of $\beta$ and $s$ to describe the strainstress behavior of the soil for loading conditions. In equation (2), the initial loading curve of the Modified Konder-Zelaso model is shown, where the parameters denoted with $*$ are the parameters normalized by vertical consolidation stress:

$$
\tau=f(\gamma)=\frac{G_{m 0}^{*} \gamma}{1+\beta\left(G_{m 0}^{*} \gamma / \tau_{m o}^{*}\right)^{s} .}
$$

An initial equivalent viscous damping ratio representing the difference between the measured and analytical damping is defined to improve the performance of the Konder-Zelaso model at moderate-level and large-level strains. Equation (3) shows the equivalent viscous damping ratio, where $\lambda_{0}$ is the viscous damping ratio, which is a function of a given strain $\gamma$, and $\gamma_{\mathrm{c} 0}$ is the cyclic shear strain amplitude:

$$
\lambda_{0}=\frac{4}{\pi} \frac{\int_{0}^{\gamma_{c 0}} f(\gamma) \mathrm{d} \gamma}{f\left(\gamma_{c 0}\right) \gamma_{c 0}}-\frac{2}{\pi} .
$$

During the subsequent loading cycle, the degraded backbone curve is following the Masing criteria. In equation (4), the parameters denoted with $*$ represent the normalized shear modulus and stress, respectively, where $G_{m t}$ is the shear modulus at time $t$ and $\tau_{m t}$ is the cyclic shear stress at time $t$ :

$$
\tau^{*}=f^{*}(\gamma)=\frac{G_{m t}^{*} \gamma}{1+\beta\left(G_{m t}^{*} / \tau_{m t}^{*} * t|\gamma|\right)^{s}} .
$$

A strain-based pore pressure generation model is used in effective stress analysis. The modulus and stress reduction models represent the reduction of soil stiffness caused by the excess pore water generation. In equations (5) and (6), the modulus and stress are expressed in terms of the residual excess pore pressure, respectively:

$$
\begin{gathered}
G_{m t}^{*}=G_{m o}^{*} \sqrt{1-u^{*}}, \\
\tau_{m t}^{*}=\tau_{m 0}^{*}\left[\left(1-u^{*}\right)^{v}\right],
\end{gathered}
$$

where $u^{*}$ is the normalized residual excess pore water pressure and $v$ is a constant to improve the modeling of the stress degradation model.

The dynamic equilibrium equation in equation (7), is solved at each time step using the time-domain Newmark's $\beta$ algorithm.

$$
[M]\{\ddot{u}\}+[C]\{\dot{u}\}+[K]\{u\}=f(t),
$$

where the $[M]$ is the mass matrix, $[C]$ is the viscous damping matrix, $[K]$ is nonlinear stiffness matrix, $\{u\}$ is the relative displacement of the mass to the base, $\{\dot{u}\}$ is the relative velocity of the mass to the base, and $\{\ddot{u}\}$ is the relative acceleration of the mass to the base.

The viscous damping is expressed in equation (8), where $\alpha_{R}$ and $\beta_{R}$ are the coefficients of Rayleigh damping, and $m$ and $k$ are the matrix elements of the mass and stiffness, respectively:

$$
c=\alpha_{R} m+\beta_{R} k
$$

In the paper, in order to obtain the pore water pressure generation, the triggering time of liquefaction, and the motion beneath the liquefiable soil, one-dimensional fullycoupled effective stress analysis was conducted in D-mod 2000.

\section{Overview of the Simplified Method}

The calculation with the proposed simplified method is conducted in the following steps to predict the liquefactioninduced lateral spreading:

(1) Determine the triggering time of liquefaction and the motion used in the Newmark sliding block method.

To identify the triggering time of liquefaction, the time history of pore water pressure time or the time history of excess pore water pressure ratio is recoded when conducting the effective stress analysis. When the liquefaction of the site is identified, the acceleration time history beneath the liquefied soil can be obtained from the effective stress analysis.

To perform the effective stress analysis, the one-dimensional soil profile susceptible to liquefaction is used. Input parameters including the thickness of the soil layer, shear velocity or shear modulus, and the saturated unit weight of each soil layer are used. Both the soil profile and the soil properties used in the analysis are established from the case-history documentation. When the soil properties are not available from the case-history documentation, the soil properties are estimated based upon the soil types. The representative modulus reduction and damping ratio curve for soil deposits are selected from empirical curves based upon the soil types and then fitted by the MKZ (Modified Konder-Zelasko) constitutive model. The pore water pressure was simulated using the PWP model implemented in D-mod 2000. To characterize the effects of the sitespecific motions on the lateral spreading, the motions applied at the base of the soil profile are selected from NGA-west 2 database [22], and the free-filed motions recorded at or close to the site are used. When the downhole motion is available, the motion is directly applied at the corresponding depth.

(2) Determine the residual shear strength of the liquefied soil.

The postliquefaction yield acceleration is the pseudoacceleration corresponding with the minimum safety factor of 1.0. The calculation of 
postliquefaction yield acceleration is carried out by the limit equilibrium method (i.e., Morgenstern-Price method [23]) based upon the two-dimensional soil profile and the residual shear strength of the liquefied soil. The input parameters, including unit weight, internal friction angle, and the cohesion for each soil layer are used in the limit equilibrium analysis.

(3) Determine the yield acceleration for the site.

As for the residual shear strength of the liquefied soil, it is the minimum shear strength of the liquefied soil at the large strain state. The residual shear strength of liquefiable soil is estimated by the Idriss and
Boulanger relationship [24], which correlates the residual shear strength to the SPT blow count of the liquefiable soil and the overburden effective stress. The ratios of residual shear strength to the vertical effective stress are shown in equations (9) and (10), respectively. For the two equations, equation (9) is the lower bound curve from Idriss and Boulanger relationship [24], corresponding to the condition that the void redistribution effects are important, and equation 10 is the upper curve from Idriss and Boulanger relationship [24], corresponding to the condition that the void redistribution effects are negligible:

$$
\begin{aligned}
& \frac{S_{u}}{\overrightarrow{\sigma_{v o}}}=\exp \left\{\frac{\left(N_{1}\right)_{60-c s}}{16}+\left(\frac{\left(N_{1}\right)_{60-c s}-16}{21.2}\right)^{3}-3.0\right\} \\
& \frac{S_{u}}{\sigma_{v o}}=\exp \left\{\frac{\left(N_{1}\right)_{60-c s}}{16}+\left(\frac{\left(N_{1}\right)_{60-c s}-16}{21.2}\right)^{3}-3.0\right\} *\left\{1+\exp \left(\frac{\left(N_{1}\right)_{60-c s}}{2.4}-6.6\right)\right\},
\end{aligned}
$$

where $S_{u}$ is the shear strength mobilized at large deformation, $\sigma_{\nu 0}$ is the prefailure effective vertical stress above the liquefied layer, $\left(N_{1}\right)_{60-c s}$ is the equivalent clean sand SPT blow count of the liquefied soil.

(4) Conduct the Newmark sliding block analysis to calculate the liquefaction-induced lateral spreading using the yield acceleration corresponding with the residual shear strength of liquefied soil and the motion beneath the liquefied soil starting from the triggering time of liquefaction.

When the motion beneath the liquefiable soil, the triggering time of liquefaction, and the postliquefaction yield acceleration are obtained, the liquefaction-induced lateral spreading is calculated by Newmark sliding block method. As the lateral spreading is the movement of gently sloping soil, the calculated displacement is the downslope movement in the Newmark sliding block method.

\section{Estimation of Liquefaction-Induced Lateral Spreading Using the Simplified Method}

To evaluate the accuracy of the proposed simplified method, five well-recorded case histories were presented and the lateral spreading for each case history was calculated in this paper.

4.1. Case 1: Wildlife Site Case. The lateral spreading and pore water pressure generation were recorded at Wildlife site in the 1987 Superstition Hills earthquake $\left(M_{w}=6.5\right)$, California. The estimated PGA of the earthquake was reported as $0.21 \mathrm{~g}$
[25]. The lateral spreading reached $0.18 \mathrm{~m}$ and liquefaction was confirmed by the pore water pressure instruments installed at the site. To analyze the site in the nonlinear effective stress analysis, a typical cross section of Wildlife site is presented in Figure 1. The water table and the shear wave velocity profile are shown in Figure 1. There are four layers of soil at the site: Units $A, B 1, B 2$, and $C$, respectively. Unit $A$ consists of silt with a thickness of $2.5 \mathrm{~m}$ and it is underlain by Unit $B$, which is identified as the liquefiable layer, a silty sand layer, with a thickness of $3.7 \mathrm{~m}$. Unit $B$ consists of two subunits $B 1$ and $B 2$, respectively. The thickness of Units $B 1$ and $B 2$ is $1.0 \mathrm{~m}$ and $2.7 \mathrm{~m}$, respectively. Below Unit $B$ is Unit $C$, consisting of thick clay with a thickness of $5.8 \mathrm{~m}$.

In Table 1, the unit weight, shear wave velocity (based upon the shear wave profile in Figure 1), the shear modulus (estimated based upon the unit weight and shear wave velocity), the modulus reduction, and the damping ratio curve for each soil layer are summarized. For Units $A, B 1$, and $B 2$, the modulus reduction and damping ratio curve were developed based upon the empirical curves by Seed and Idriss [27], and the modulus reduction and damping ratio curve of Unit $\mathrm{C}$ were based upon the curves developed by Vucetic and Dobry [28].

A downhole motion denoted as IVW-090 was recorded by the SM1 strong motion station, which was at the base of the silty sand layer at the lateral spreading site [25]. The PGA of the downhole motion in Figure 2 is $0.106 \mathrm{~g}$. The motion was applied at the depth of $7.5 \mathrm{~m}$ (i.e., the depth at which the downhole motion was recorded) below the ground surface in the effective stress analysis.

Based upon the effective analysis, Units B1 and B2 liquefied during the shaking. The triggering of liquefaction 
Shear wave velocity $(\mathrm{m} / \mathrm{s})$

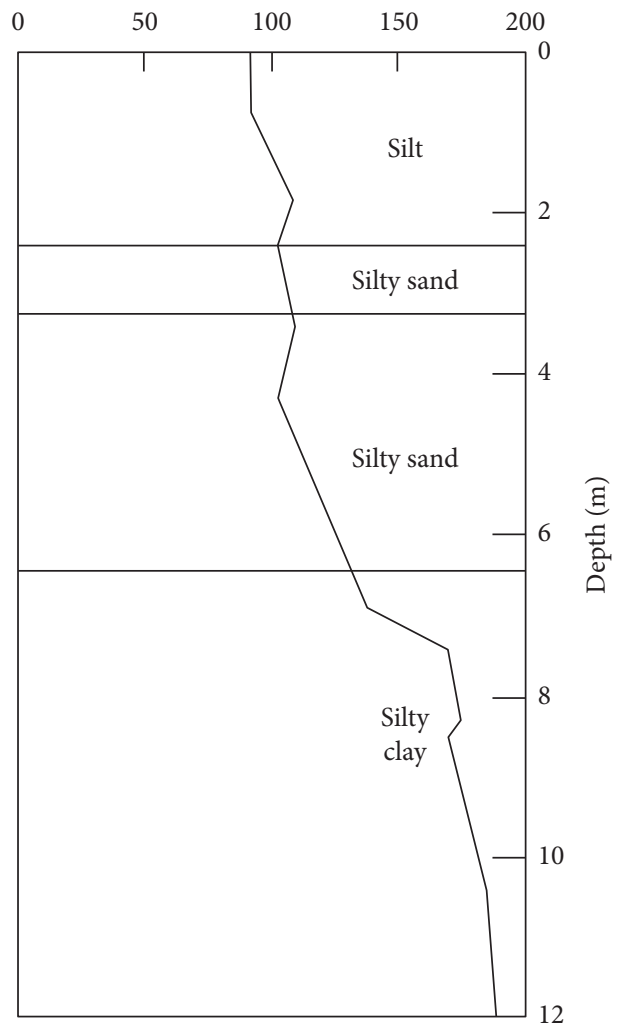

FIgure 1: Profile of the wildlife site case after Ching and Glaser [26].

TABLE 1: Soil parameters used for nonlinear effective analysis.

\begin{tabular}{lcccccc}
\hline Soil layers & Unit weight $\left(\mathrm{kN} / \mathrm{m}^{3}\right)$ & Thickness $(\mathrm{m})$ & $V_{s}(\mathrm{~m} / \mathrm{s})$ & Initial modulus $(\mathrm{kPa})$ & Modulus reduction curves & Damping ratio curves \\
\hline Unit A & 19.4 & 2.5 & 90 & 16171 & Sand, lower bound [27] & Sand, lower bound [27] \\
Unit B1 & 19.4 & 1.0 & 110 & 24174 & Sand, lower bound [27] & Sand, lower bound [27] \\
Unit B2 & 19.4 & 2.7 & 120 & 28780 & Sand, lower bound [27] & Sand, lower bound [27] \\
Unit C & 19.4 & 5.8 & 180 & 64756 & PI =30 [28] & PI = 30 [28] \\
\hline
\end{tabular}

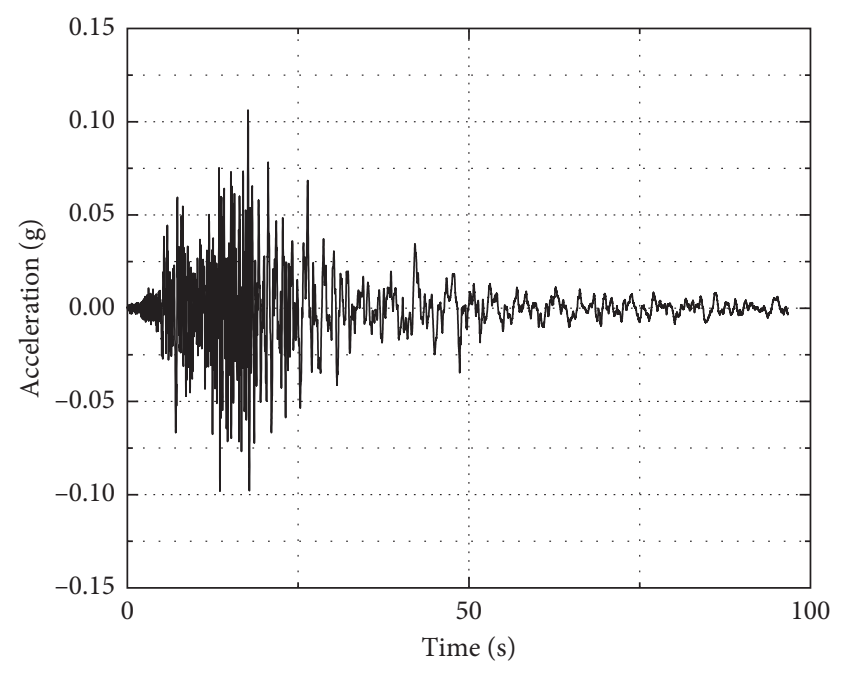

— IVW-090 (within motion)

FIgURE 2: Input motions at the depth of $7.5 \mathrm{~m}$ below the surface: IVW-090. was in accordance with the field observation during the 1987 Superstition Hills earthquake, and the triggering time of liquefaction was $22.94 \mathrm{~s}$ for Unit B2.

The postliquefaction yield acceleration of the Wildlife site case was calculated based upon the two-dimensional soil profile developed by Makdisi [29], as shown in Figure 3. Using the Idriss and Boulanger relationship [24], the residual shear strength of Unit B was estimated as $6.76 \mathrm{kPa}$ based upon the effective overburden stress of $61.7 \mathrm{kPa}$ and the equivalent clean sand blow count, $\left(N_{1}\right)_{60}=10.3$. By conducting equilibrium analysis, the postliquefaction yield acceleration of $0.03 \mathrm{~g}$, the slip surface, and the liquefied soil layer are shown in Figure 4. In Table 2, the calculated lateral spreading by the simplified method is shown. Note: the normal and inverse directions are the integrations of the positive and negative motions of the velocity time history corresponding with the dynamic input motion, respectively.

4.2. Case 2: Monterey Bay Aquarium Research Institute. In the 1989 Loma Prieta earthquake $\left(M_{w}=7.0\right)$ [30], the estimated PGA of the site was $0.25 \mathrm{~g}$. Extensive lateral 


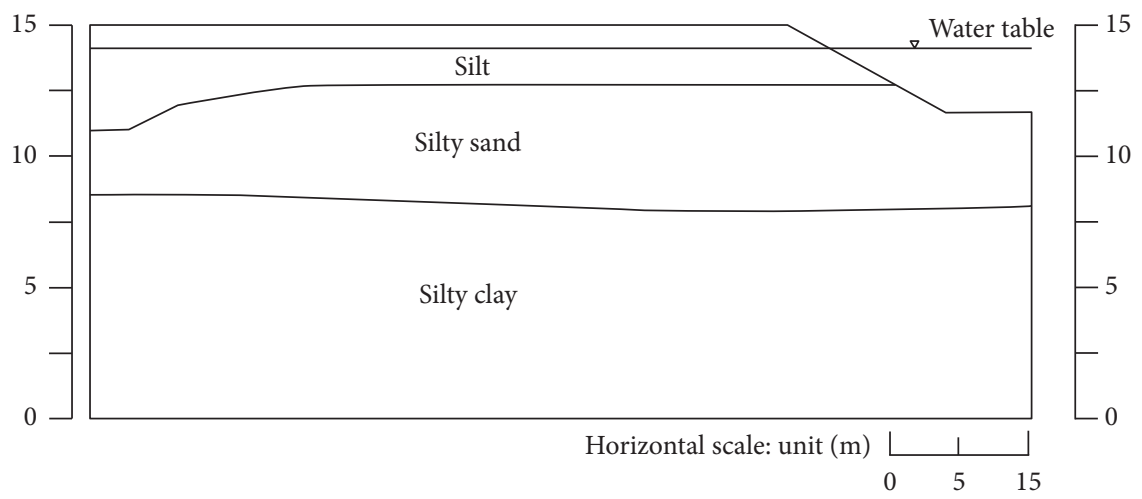

FIgURE 3: Soil profile after Makdisi [29] for limit equilibrium analysis.

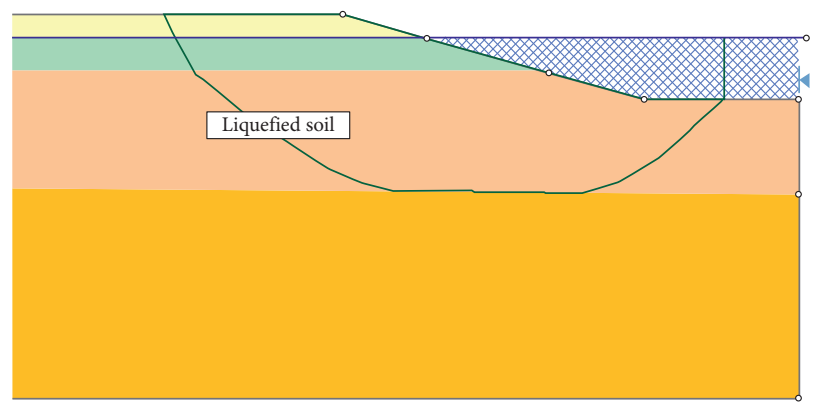

FIGURE 4: Postliquefaction yield acceleration of wildlife site.

TABLE 2: Lateral spreading calculated by the simplified method (the reported displacement is reported as $0.18 \mathrm{~m}$ ).

\begin{tabular}{lcc}
\hline Motion name & Rigid block-normal $(\mathrm{m})$ & Rigid block-inverse $(\mathrm{m})$ \\
\hline IVW-090 (downhole motion) & 0.02 & 0.01 \\
\hline
\end{tabular}

spreading was reported in the area of Moss Landing, and several slope inclinometers were placed along Sandholdt road to record the lateral displacement before the earthquake struck. MBARI (Monterey Bay Aquarium Research Institute) facilities along Sandholdt road suffered the earthquake and ground cracks were reported. The lateral spreading toward the sea was $0.28 \mathrm{~m}$ based upon the inclinometer SI-2. To conduct the effective stress analysis, the subsurface of inclinometer SI-2 [30] shown in Figure 5 was analyzed in the paper.

The liquefiable layer was recognized as the sand layer below the ground surface. In Figure 5, the $4.6 \mathrm{~m}$ thick sand with interlayered clayey silt was underlain by the $1.4 \mathrm{~m}$ thick clayey silt, which did not liquefy during the earthquake. The dense sand reported below the clayey silt was $4.1 \mathrm{~m}$ in thickness. Two more layers of silty clay with a total thickness of $11.0 \mathrm{~m}$ were reported at the bottom of the soil profile based upon the site investigation by Boulanger et al. [30]. The thickness of the first silty clay was $3.2 \mathrm{~m}$ and the second silty clay with interlayered sand was $7.8 \mathrm{~m}$.

Table 3 summarizes the soil parameters used in the effective stress analysis. The shear wave velocity was estimated based upon the SPT blow counts and the initial shear modulus was estimated based upon the unit weight and shear wave velocity of each soil layer. The modulus reduction curve and damping ratio curve of sand with interlayered clayey silt were developed from the empirical model by Darendeli [31]. The clayey silt, silty clay at the depth of $4.56 \mathrm{~m}$ and $10.1 \mathrm{~m}$, adopted the empirical curves by Vecetic and Dobry [28]. The modulus reduction curve and damping ratio curve for sand were developed based upon the cohesionless model by EPRI [32].

Two input motions in the PEER Strong Ground Motion Database [22] were used in the analysis. The two motions were recorded at the basement of Monterey city hall, a twostory building. The soil condition at the strong motion station was classified as a weak rock with a shear wave velocity, $V_{s, 30}$ of $638.63 \mathrm{~m} / \mathrm{s}$ based upon Chiou [33]. As shown in Figure 6, the PGA of the two motions were scaled to a PGA of $0.25 \mathrm{~g}$ to generate the input motions denoted as $\mathrm{MCH}-000$ and MCH-090, respectively.

The corresponding triggering time of liquefaction of the sand layer with interlayered clayey silt was $16.78 \mathrm{~s}$ and $18.72 \mathrm{~s}$ for the two motions: $\mathrm{MCH}-000$ and $\mathrm{MCH}-090$, respectively. The motions beneath the liquefied soil starting from the triggering time of liquefaction (i.e., sand with interlayered clayey silt) were used as the input motions in the simplified method. The yield acceleration analysis of the site was conducted using the soil profile shown in Figure 5. The SPT blow count value, $\left(N_{1}\right)_{60}$, of the liquefiable soil, is 


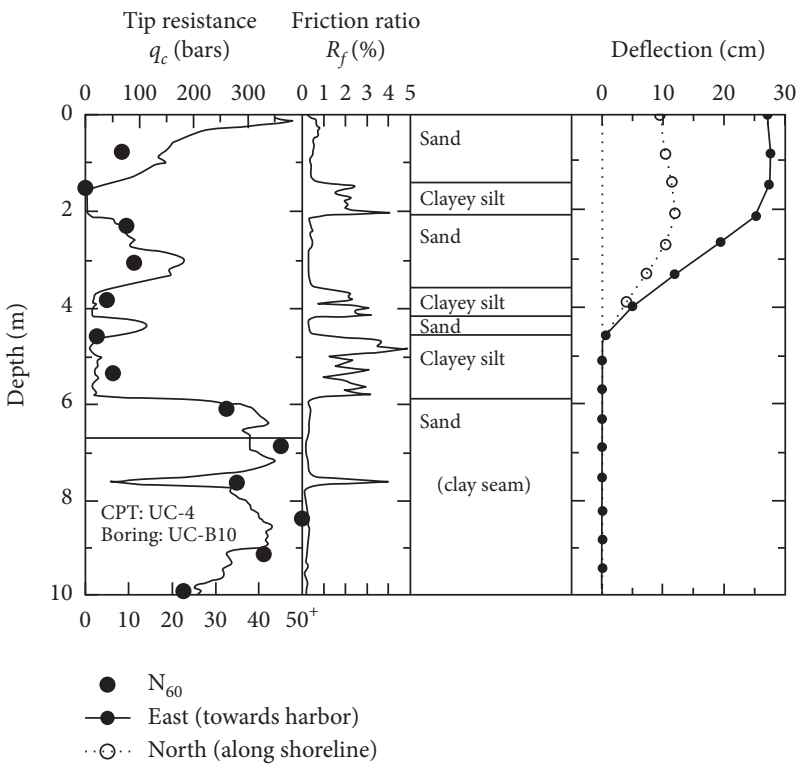

(a)

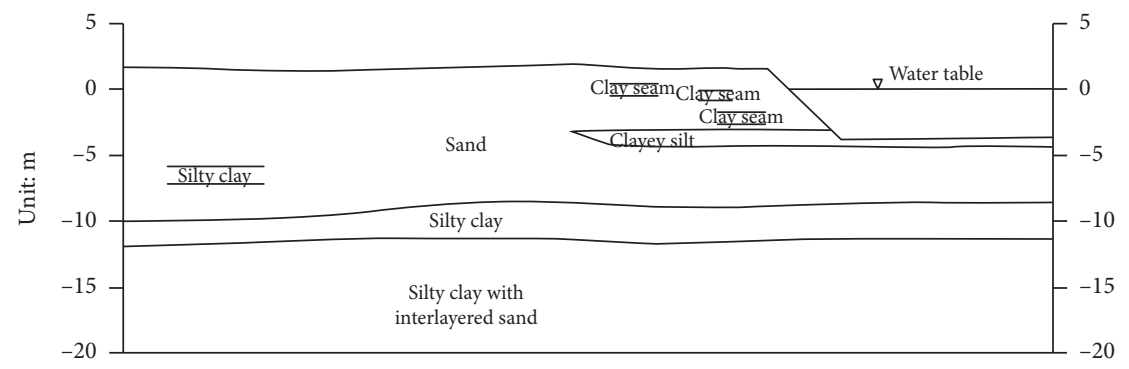

(b)

FIGURE 5: Soil profiles by Boulanger et al. [30]. (a) Soil profile through SI-2 inclinometer. (b) Soil profile at building No. 4 at MBARI facilities.

TABLE 3: Soil parameters used for nonlinear effective analysis.

\begin{tabular}{|c|c|c|c|c|c|c|}
\hline Soil layers & $\begin{array}{l}\text { Unit weight } \\
\left(\mathrm{kN} / \mathrm{m}^{3}\right)\end{array}$ & $\begin{array}{l}\text { Thickness } \\
(\mathrm{m})\end{array}$ & $\begin{array}{c}V_{s} \\
(\mathrm{~m} / \mathrm{s})\end{array}$ & $\begin{array}{c}\text { Initial modulus } \\
(\mathrm{kPa})\end{array}$ & $\begin{array}{c}\text { Modulus reduction } \\
\text { curves }\end{array}$ & $\begin{array}{c}\text { Damping ratio } \\
\text { curves }\end{array}$ \\
\hline $\begin{array}{l}\text { Sand with interlayered } \\
\text { clayey silt }\end{array}$ & 16.0 & 4.56 & 218.0 & $7.7 e 4$ & $\mathrm{PI}=0,0.25 \mathrm{~atm}[31]$ & $\mathrm{PI}=0,0.25 \mathrm{~atm}[31]$ \\
\hline Clayey silt & 17.0 & 1.40 & 158.0 & $4.35 e 4$ & $\mathrm{PI}=15[28]$ & $\mathrm{PI}=15[28]$ \\
\hline Sand & 18.0 & 4.14 & 218.0 & $8.71 e 4$ & Cohesionless soil [32] & $\begin{array}{c}\text { Cohesionless soil } \\
\text { [32] }\end{array}$ \\
\hline Silty clay & 17.0 & 3.20 & 138.0 & $3.33 e 4$ & $\mathrm{PI}=30[28]$ & $\mathrm{PI}=30[28]$ \\
\hline Silty clay & 18.0 & 7.80 & 238.0 & $10.04 e 5$ & $\mathrm{PI}=30[28]$ & $\mathrm{PI}=30[28]$ \\
\hline
\end{tabular}

reported as 10.0 based upon Boulanger et al. [30], and the vertical effective stress of $63.7 \mathrm{kPa}$ was used to estimate the postliquefaction residual shear strength of the liquefiable soil. The residual shear strength of the liquefiable soil was estimated as $6.3 \mathrm{kPa}$ by the Idriss and Boulanger relationship [24].

The yield acceleration was determined as $0.007 \mathrm{~g}$ by the limit equilibrium analysis, as shown in Figure 7. In Table 4, the predicted lateral spreading using postliquefaction motion beneath the liquefied soil and the recorded lateral spreading are listed. Note: the normal and inverse directions are the integrations of the positive and negative motions of the velocity time history corresponding with the acceleration time history, respectively.

4.3. Case 3: Northridge Case. The 1994 Northridge earthquake caused severe damage to the Los Angeles metropolitan area. The moment magnitude of the earthquake, $M_{w}$, was 6.7, and the PGA of the site was estimated as $0.51 \mathrm{~g}$ [34]. Lateral spreading was observed due to the ground shaking. The lateral spreading at the Wynne Avenue site is shown in Figure 8, which was one of the three representative sites located in the San Fernando Valley investigated by Holzer 


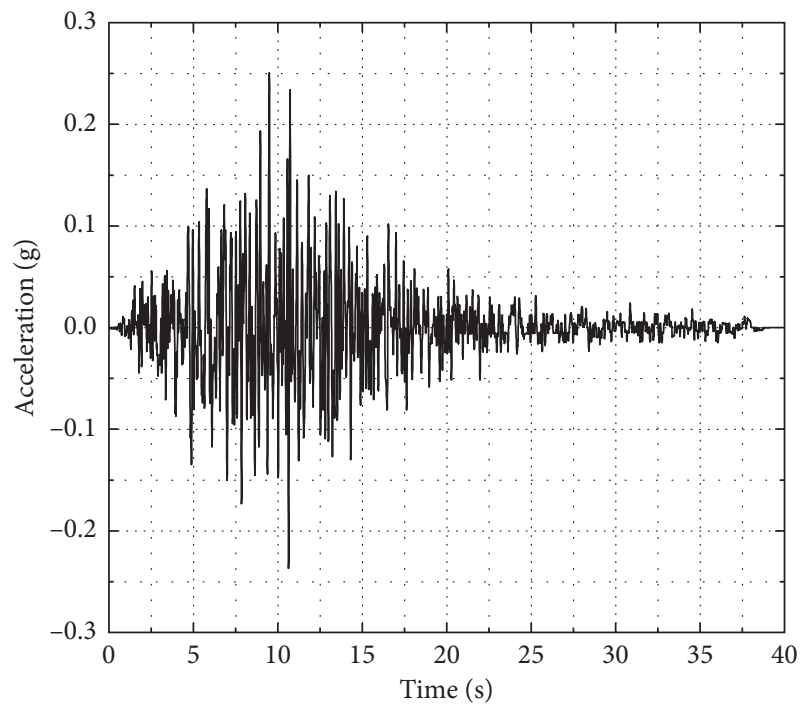

- MCH 000

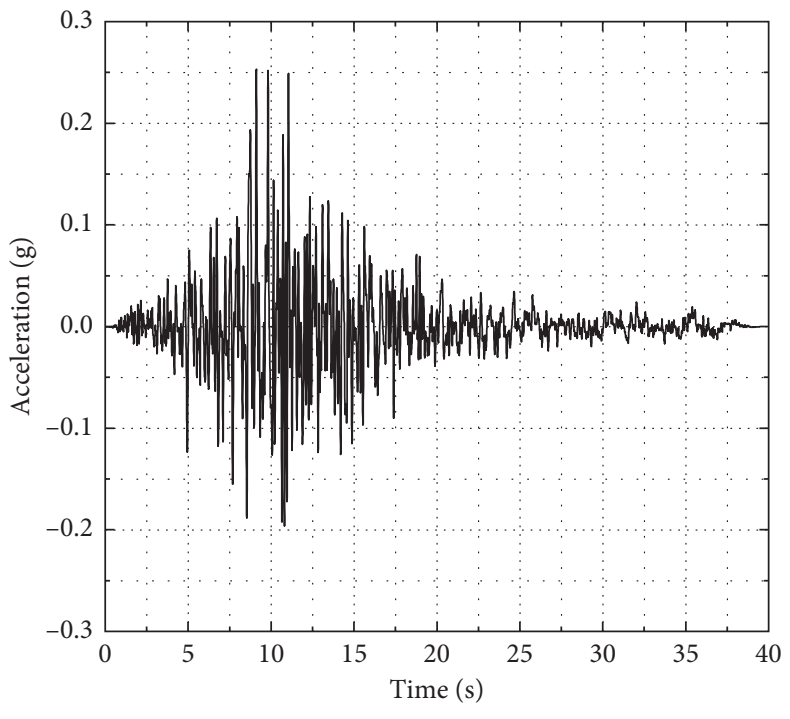

- MCH 090

(a)

(b)

Figure 6: Input motions at the base. (a) MCH-000 and (b) MCH-090.

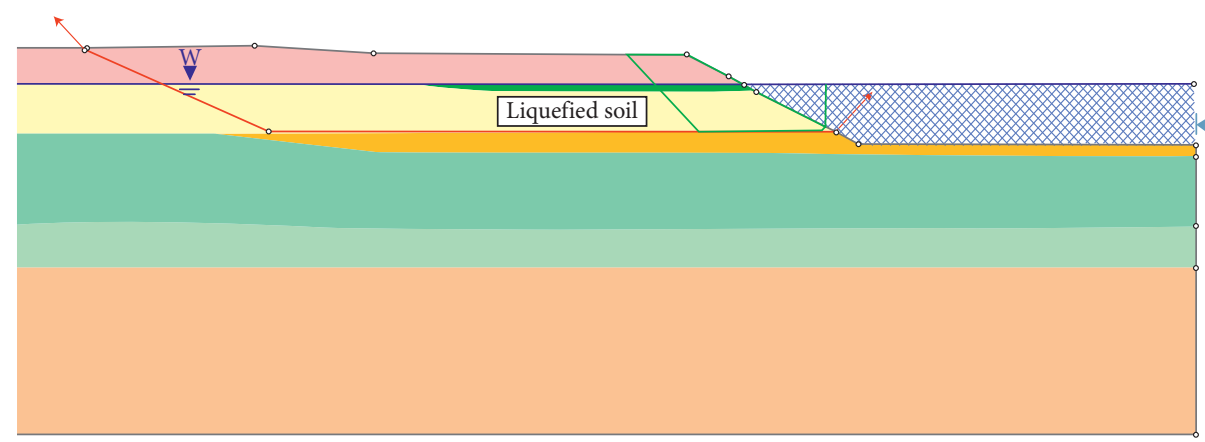

Figure 7: Postliquefaction yield acceleration of building No. 4 at MBARI facilities.

TABLE 4: Lateral spreading calculated by the simplified method (the reported displacement is reported as $0.28 \mathrm{~m}$ ).

\begin{tabular}{lcc}
\hline Motion name & Rigid block-normal $(\mathrm{m})$ & Rigid block-inverse $(\mathrm{m})$ \\
\hline MCH-000 & 0.17 & 0.16 \\
MCH-090 & 0.18 & 0.17 \\
\hline
\end{tabular}

et al. [34], and it was reanalyzed in the paper. Several drilling investigations were conducted by Holzer et al. [34]. It was concluded that the failure area was a block with a size of $150 \mathrm{~m}$ in length and $12 \mathrm{~m}$ in width, and the sloping of the gently ground was around $1.3 \%$. The groundwater table was $4.3 \mathrm{~m}$ below the ground surface.

A one-dimensional soil column was developed based on Figure 8. Four units of soil were identified in the soil profile: the ground surface was underlain by Unit A, silty sand soil layer, and the thickness of Unit A was $2.3 \mathrm{~m}$; Unit B consisting of $3.2 \mathrm{~m}$ thick lean clay was below Unit A, and then the first layer of Unit $\mathrm{C}$ with interlayers of Units C1 and C2 was below Unit B. Unit C consisted of silty sand and lean clay. Units $\mathrm{C} 1$ and $\mathrm{C} 2$ were susceptible to liquefaction and identified as silty sand. Unit $\mathrm{C}$ layer between Unit $\mathrm{C} 1$ and Unit C2 layer was $2.7 \mathrm{~m}$ in thickness, Unit $\mathrm{C} 1$ was of $2.2 \mathrm{~m}$ in thickness, and Unit C2 was of $0.8 \mathrm{~m}$ in thickness, respectively. Unit $\mathrm{C}$ layer below Unit $\mathrm{C} 2$ was $3.8 \mathrm{~m}$ in thickness. Below Unit C, the $2 \mathrm{~m}$ thick Unit D was identified as medium silty sand. In Table 5 , the soil parameters, the shear modulus reduction curves, and the damping ratio curves are tabulated. The modulus reduction curve and damping ratio curve were developed by the empirical curves by Darendeli [31]. Two layers of Unit C with different soil properties, representing the soil layers at two different depths, are listed in Table 5.

The input motions are available at the PEER Strong Ground Motion Database [22]. The two motions were recorded at the ground level of the strong motion station, Canoga Park-Topanga Can, a one-story building, of which the site condition is classified as firm soil [33]. The shear wave velocity, $V_{s, 30}$, of the soil below the strong motion station is $267.49 \mathrm{~m} / \mathrm{s}$ based upon Chiou et al. [33]. The plot of 


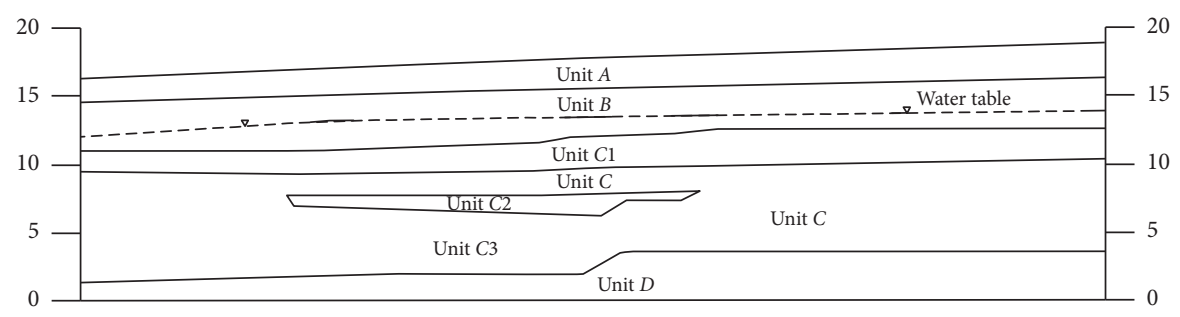

Figure 8: Soil profile of the Wynne Street after Holzer et al. [34].

the two acceleration time histories is shown in Figure 9, and both motions are scaled to the estimated PGA of $0.51 \mathrm{~g}$ by Holzer et al. [34]. The two scaled acceleration time histories, denoted as CNP-106 and CNP-196, are used in the analysis. The liquefiable soil was recognized as Unit $\mathrm{C} 1$. The triggering time of liquefaction at the site was $6.16 \mathrm{~s}$ and $6.64 \mathrm{~s}$ for the input motions, CNP-106, and CNP-196, respectively. The residual shear strength of the liquefiable soil was $22.8 \mathrm{kPa}$ for Unit C1 based on the SPT blow count, $\left(N_{1}\right)_{60}=11.6$, and effective vertical stress, $124.3 \mathrm{kPa}$, by Idriss and Boulanger [24]. The yield acceleration of the soil profile was $0.15 \mathrm{~g}$ calculated with the limit equilibrium method, as shown in Figure 10. In Table 6, the displacements of the calculated and recorded lateral spreading are shown.

4.4. Case 4: Port Island Case. The Kobe earthquake in 1995 caused significant damage to the city area of Kobe, and the estimated PGA of the earthquake was $0.34 \mathrm{~g}$ [35]. The moment magnitude of the earthquake, $M_{w}$, was equal to 6.9 based upon Yang [36]. The liquefaction was reported along the waterfront in the reclaimed areas and extensive failures were observed in these areas. One of the most observed phenomena was that the quay walls failed to stand and caused the failures of the nearby facilities.

One representative quay wall in Port Island was analyzed in the paper. The soil profile with the water table at a depth of $2.4 \mathrm{~m}$ [37] used in the analysis is shown in Figure 11. Six layers of soil are below the ground surface, and the ground surface was underlain by backfill of sandy gravel, of which the thickness was $19 \mathrm{~m}$. The $8 \mathrm{~m}$ thick alluvial clay was below the sandy gravel, and the soil was underlain by alluvial sand with a thickness of $10 \mathrm{~m}$ in turn; the following soil below the sand layer was diluvial sandy gravel, diluvial clay, and sand with gravel in order. The thickness of diluvial sandy gravel was $23 \mathrm{~m}$, the thickness of the diluvial clay was $22 \mathrm{~m}$, and the sand with gravel was $6 \mathrm{~m}$ in thickness at the bottom of the soil profile. The unit weight, thickness of soil, shear modulus, shear velocity, modulus reduction curve, and damping ratio curves for each soil layer used in the analysis are summarized in Table 7 . The modulus reduction curve and damping ratio curve of the sandy gravel were estimated by the curves developed by Seed [38]. For the other four soils, the dynamic curves are modeled by Darendeli [31].

The strong motion recorded at the site was used in the analysis, and the downhole motion denoted as PRI-000 $(\mathrm{PGA}=0.346 \mathrm{~g})$ is plotted in Figure 12. The motion was recorded at the base of the port island strong motion station house (evaluation is $-83 \mathrm{~m}$ ). The soil profile below the strong motion instruments is shown in Figure 11. The site condition was classified as firm soil with a shear wave velocity $V s_{30}$ equal to $198 \mathrm{~m} / \mathrm{s}$. Based on the nonlinear analysis results, it is shown that the backfill soil (sandy gravel) liquefied during the earthquake and the triggering time of the liquefaction was 16.6s. The corrected SPT blow count, $\left(N_{1}\right)_{60}$, was estimated as 10.8 of the liquefiable soil based upon an $\left(N_{1}\right)_{60-c s}$ value of 15.3 [39] and the effective overburden stress was equal to $153.8 \mathrm{kPa}$. The soil profile developed by Yang [36] was used for limit equilibrium analysis, as shown in Figure 13. The yield acceleration was $0.04 \mathrm{~g}$ using the residual shear strength, $17.0 \mathrm{kPa}$, of liquefiable soil by the estimation method of Idriss and Boulanger [24], as shown in Figure 14. In Figure 14, the slip surface and the liquefied soil are also shown. The motions beneath the backfill (sandy gravel) soil starting at the triggering time of liquefaction and the postliquefaction yield acceleration were used in Newmark displacement analysis and the predicted lateral spreading is summarized in Table 8.

4.5. Case 5 Chi-Chi Case. The lateral spreading recorded at Wufeng site was analyzed in the paper. The earthquake with a moment magnitude, $M_{w}, 7.6$ in 1999 near the Chi-Chi town in the center of Taiwan brought loss and disasters to the area. The estimated PGA of the earthquake was $0.81 \mathrm{~g}$ [40]. Landslides and liquefaction were observed along the active fault line which triggered the earthquake. In the city Wufeng, extensive liquefaction was identified in the area as the sediment boil and ground fissures were observed after the earthquake.

The Wufeng site $M$ is located at a parking lot, as shown in Figure 15. During the earthquake, the ground moved toward a creek as far as $1.62 \mathrm{~m}$ in the south of the parking lot. The water table was about $2 \mathrm{~m}$ below the ground surface. The ground surface was underlain by four layers of soil: the first layer was the artificial fill with a thickness of $1.0 \mathrm{~m}$. The second layer was the soil of gray, loose to medium dense silty sand, which was classified as SM (silty sand). The thickness of the SM layer was about $4.5 \mathrm{~m}$. The silt, classified as ML (lean silt), was sandwiched by SM and artificial fill. Table 9 shows the soil parameters: unit weight, thickness, shears wave velocity, initial modulus, modulus reduction curve, and damping ratio curve used in the analysis. For the soil classified as fill and GM, the dynamic curves were based upon the empirical curves by EPRI [32]. The dynamic curves of soil classified as SM were based upon the curves by Seed [27]. 
TABLE 5: Soil parameters used for nonlinear effective analysis.

\begin{tabular}{lcccccc}
\hline $\begin{array}{l}\text { Soil } \\
\text { layers }\end{array}$ & $\begin{array}{c}\text { Unit weight } \\
\left(\mathrm{kN} / \mathrm{m}^{3}\right)\end{array}$ & $\begin{array}{c}\text { Thickness } \\
(\mathrm{m})\end{array}$ & $V_{\mathrm{s}}(\mathrm{m} / \mathrm{s})$ & $\begin{array}{c}\text { Initial modulus } \\
(\mathrm{kPa})\end{array}$ & $\begin{array}{c}\text { Modulus reduction curves } \\
{[31]}\end{array}$ & $\begin{array}{c}\text { Damping ratio curves } \\
{[31]}\end{array}$ \\
\hline Unit A & 19.7 & 2.3 & 140 & $3.93 e 4$ & $\mathrm{PI}=0,0.4 \mathrm{~atm}$ & $\mathrm{PI}=0,0.4 \mathrm{~atm}$ \\
Unit B & 20.0 & 3.2 & 89 & $1.61 e 4$ & $\mathrm{PI}=15,0.77 \mathrm{~atm}$ & $\mathrm{PI}=15,0.77 \mathrm{~atm}$ \\
Unit C1 & 23.8 & 2.2 & 170 & $7.10 e 4$ & $\mathrm{PI}=0,0.88 \mathrm{~atm}$ & $\mathrm{PI}=0,0.88 \mathrm{~atm}$ \\
Unit C & 21.0 & 2.7 & 242 & $1.25 e 5$ & $\mathrm{PI}=0,1.18 \mathrm{~atm}$ & $\mathrm{PI}=0,1.18 \mathrm{~atm}$ \\
Unit C2 & 22.5 & 0.8 & 201 & $9.27 e 4$ & $\mathrm{PI}=0,1.48 \mathrm{~atm}$ & $\mathrm{PI}=0,1.48 \mathrm{~atm}$ \\
Unit C & 21.0 & 3.8 & 166 & $5.90 e 4$ & $\mathrm{PI}=0,1.58 \mathrm{~atm}$ & $\mathrm{PI}=0,1.58 \mathrm{~atm}$ \\
Unit D & 22.0 & 2.0 & 305 & $2.09 e 5$ & $\mathrm{PI}=0,2.0 \mathrm{~atm}$ & $\mathrm{PI}=0,2.0 \mathrm{~atm}$ \\
\hline
\end{tabular}

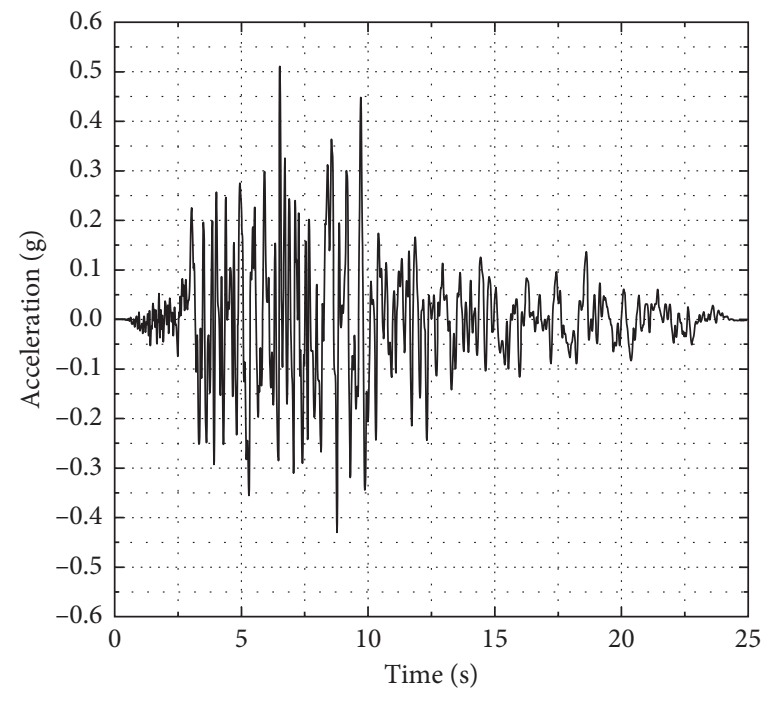

CNP 106

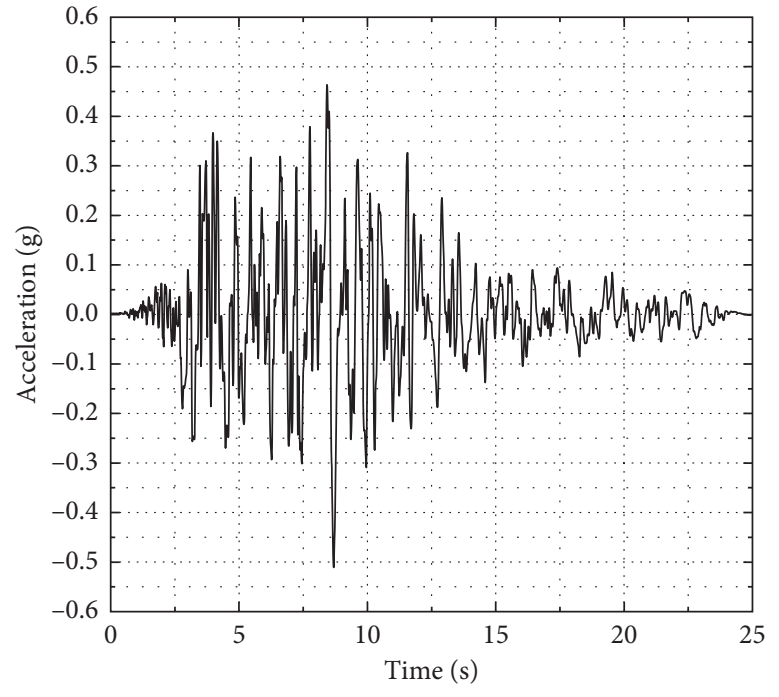

CNP 196

(a)

(b)

FIgURE 9: Input motions at the base of the soil profile. (a) CNP 106 and (b) CNP-196.

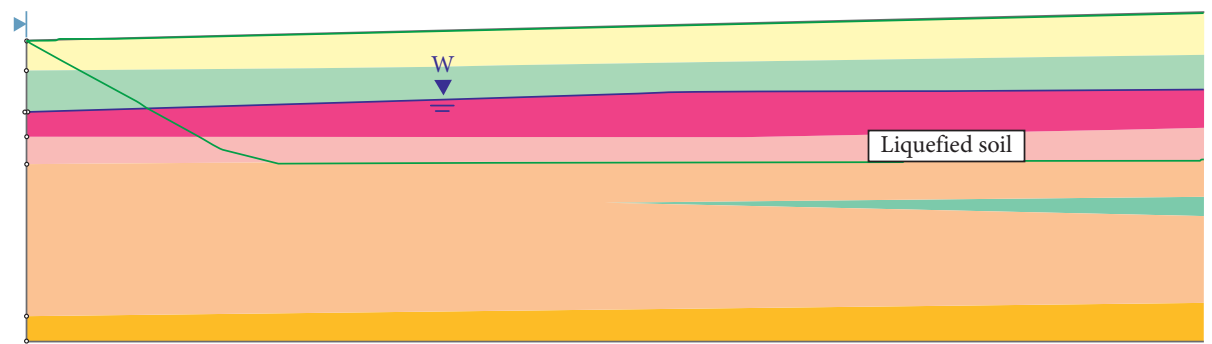

Figure 10: Postliquefaction yield acceleration calculation of the Wynne Street.

TABLE 6: Newmark displacement analysis results by the simplified method (the reported displacement is reported as $0.15 \mathrm{~m}$ ).

\begin{tabular}{lcc}
\hline Motion name & Rigid block-normal $(\mathrm{m})$ & Rigid block-inverse $(\mathrm{m})$ \\
\hline CNP-106 & 0.24 & 0.20 \\
CNP-196 & 0.15 & 0.01 \\
\hline
\end{tabular}

The motions recorded at the strong motion station were scaled to $0.81 \mathrm{~g}$, which were available at PEER Strong Ground Motion Database [22]. The strong motion station was less than $1 \mathrm{~km}$ far from the lateral spreading site and the site condition of the strong motion station was firm soil with a shear wave velocity $V_{s, 30}$ equal to $305.85 \mathrm{~m} / \mathrm{s}$. The two input motions were denoted as TCU-650e and TCU 650n. In Figure 16, the input motions used in the analysis are plotted. The triggering time of liquefaction of motion TCU-650e is $33.12 \mathrm{~s}$ and the triggering time of liquefaction for motion TCU-650n is $28.43 \mathrm{~s}$, respectively. The residual shear strength of the liquefiable soil was estimated as $8.2 \mathrm{kPa}$ based on the corrected blow count $\left(N_{1}\right)_{60}=11.5$ and effective overburden stress equals $59.8 \mathrm{kPa}$ using the estimation method by Idriss and Boulanger [24]. In Figure 17, the yield acceleration is shown as $0.075 \mathrm{~g}$ based on the soil profile, the slip surface, and the liquefied soil calculated by the limit 


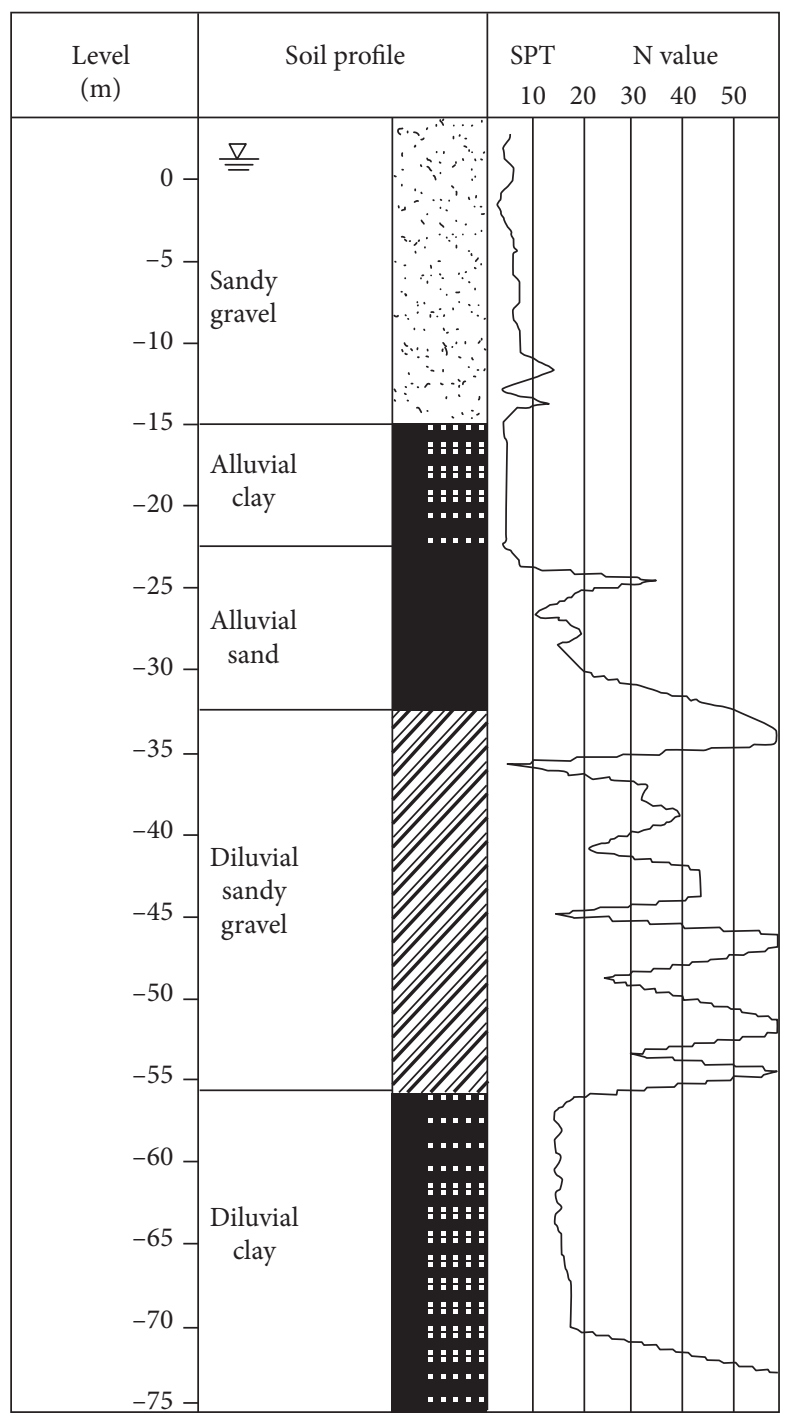

FIgUre 11: The soil profile of the Port island case developed by Inagaki [37].

TABLE 7: Soil parameters used for nonlinear effective analysis.

\begin{tabular}{|c|c|c|c|c|c|c|}
\hline Soil layers & $\begin{array}{c}\text { Unit weight } \\
\left(\mathrm{kN} / \mathrm{m}^{3}\right)\end{array}$ & $\begin{array}{l}\text { Thickness } \\
(\mathrm{m})\end{array}$ & $\begin{array}{c}V_{s} \\
(\mathrm{~m} / \mathrm{s})\end{array}$ & $\begin{array}{c}\text { Initial modulus } \\
(\mathrm{kPa})\end{array}$ & $\begin{array}{c}\text { Modulus reduction } \\
\text { curves }\end{array}$ & $\begin{array}{l}\text { Damping ratio } \\
\text { curves }\end{array}$ \\
\hline $\begin{array}{l}\text { Sandy gravel (backfill } \\
\text { soil) }\end{array}$ & 21.8 & 19.0 & 187 & $7.78 e 4$ & Gravel, average [38] & Gravel, average [38] \\
\hline Alluvial clay & 23.1 & 8.0 & 180 & $7.65 e 4$ & $\mathrm{PI}=20,3.27 \mathrm{~atm}[31]$ & $\mathrm{PI}=20,3.27 \mathrm{~atm}$ \\
\hline Alluvial sand & 18.0 & 10.0 & 245 & $1.10 e 5$ & $\mathrm{PI}=0,4.0 \mathrm{~atm}[31]$ & $\mathrm{PI}=0,4.0 \mathrm{~atm}[31]$ \\
\hline Diluvial sandy gravel & 18.0 & 23.0 & 325 & $1.94 e 5$ & $\mathrm{PI}=0,6.95 \mathrm{~atm}[31]$ & $\mathrm{PI}=0,6.95 \mathrm{~atm}[31]$ \\
\hline Diluvial clay & 20.0 & 18.0 & 303 & $1.87 e 5$ & $\mathrm{PI}=0,9.0 \mathrm{~atm}[31]$ & $\mathrm{PI}=0,9.0 \mathrm{~atm}[31]$ \\
\hline
\end{tabular}

equilibrium method. In Table 10, the predicted lateral spreading and the reported lateral spreading are shown.

\section{Comparisons of the Results by Different Prediction Methods}

Calculating the triggering time of liquefaction with the finite difference analysis, a hybrid approach based on the Newmark sliding block method, the postliquefaction yield acceleration, and the triggering time of liquefaction was also developed by the authors of this paper to predict the lateral spreading. In this section, only a brief introduction to that hybrid approach was made. The details of that hybrid approach were prepared in a separate paper. To predict the lateral spreading in the finite difference program FLAC 2D [41], the PM4sand constitutive model proposed by Boulanger and Ziotopoulou [15] was adopted to simulate the dynamic response of liquefiable sand. The plasticity sand 


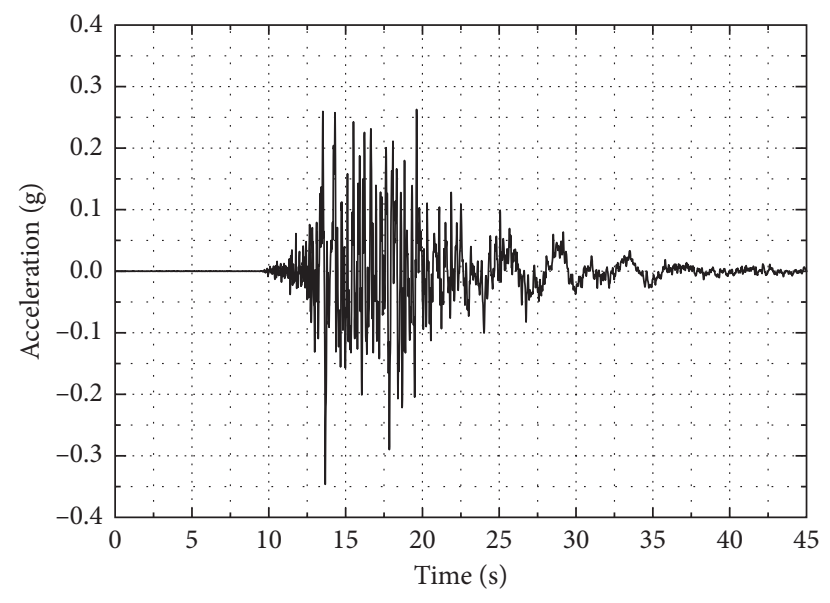

_ PRI-090 (within motion)

FIgURE 12: Input motions at the depth of $83 \mathrm{~m}$ : PRI-090.

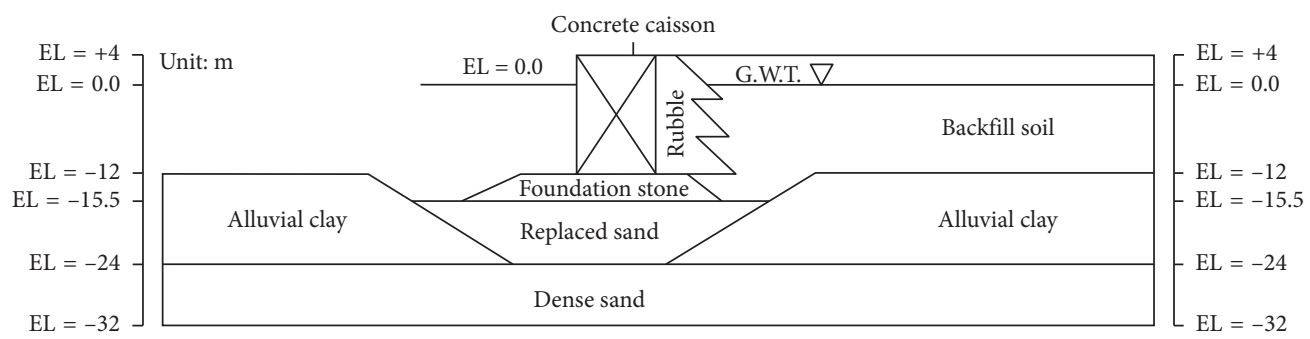

FIGURE 13: Soil profile developed after Yang [36] for limit equilibrium analysis.

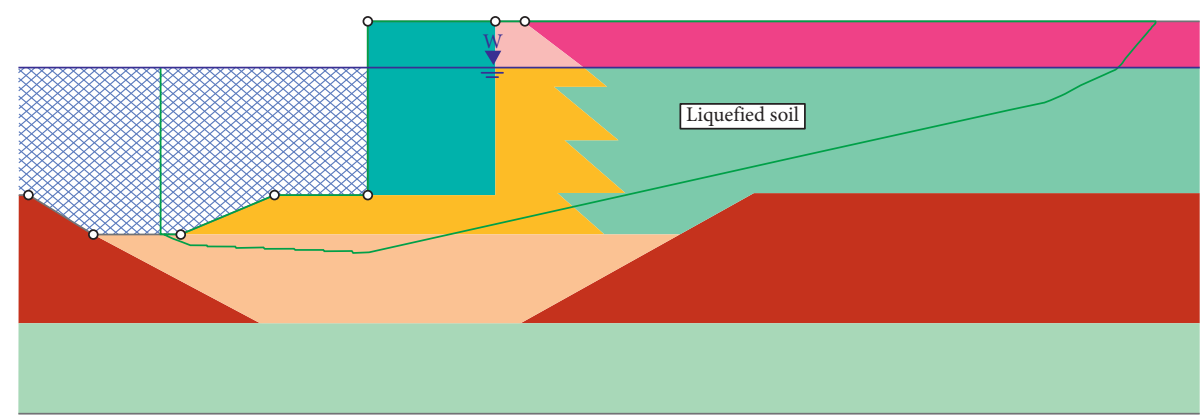

FIgURE 14: Yield acceleration calculation based upon the soil profile by Yang [36].

TABLE 8: Newmark displacement analysis results by the simplified method (the reported displacement is reported as $2.86 \mathrm{~m}$ ).

\begin{tabular}{lcl}
\hline Motion name & Rigid block-normal (m) Rigid block-inverse (m) \\
\hline PRI-090 & 1.73
\end{tabular}

model PM4sand required three primary input parameters to be adjusted based on the soil property: apparent relative density, shear modulus coefficient constant, and contraction rate parameter. In the three parameters, the apparent relative density and shear modulus coefficient were determined using the SPT blow count of the liquefiable soil, and the contraction rate parameter was backcalculated by conducting the dynamic analysis of an element undergoing cyclic loading under the condition that a target cyclic resistance ratio was reached. In the dynamic analysis, twodimensional soil profiles with the soil parameters for static and dynamic analysis were obtained based upon the documentation. Earthquake motions recorded at strong motion sites were deconvoluted by the equivalent linear analysis and then applied at the bottom of FLAC finite mesh. The pore water pressure versus dynamic time at the bottom of liquefied soil was monitored during the dynamic analysis to obtain the triggering time of liquefaction and the motion beneath the liquefied soil. The hybrid approach used the motion beneath the liquefied soil obtained from the finite difference analysis that started from the liquefaction of triggering and predicted the lateral spreading using 


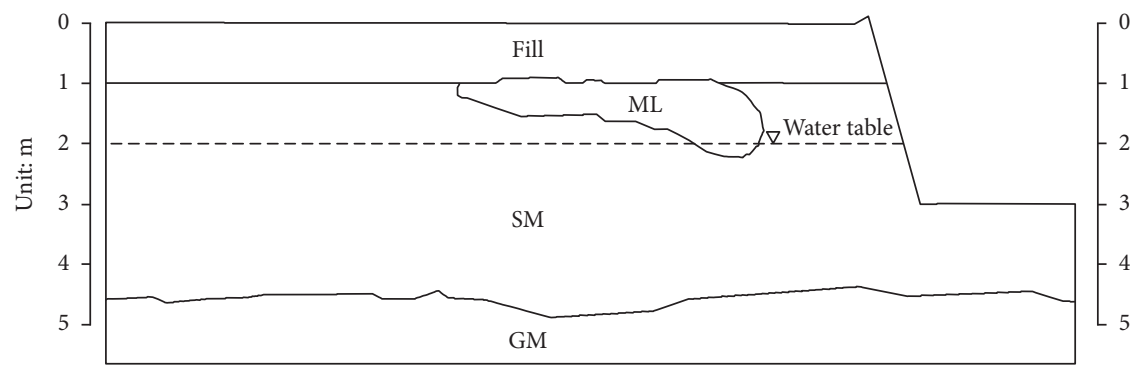

Figure 15: The soil profile of the Chi-Chi case developed by Chu et al. [40].

TABLE 9: Soil parameters used for nonlinear effective analysis.

\begin{tabular}{|c|c|c|c|c|c|c|}
\hline $\begin{array}{l}\text { Soil } \\
\text { layers }\end{array}$ & $\begin{array}{l}\text { Unit weight } \\
\left(\mathrm{kN} / \mathrm{m}^{3}\right)\end{array}$ & $\begin{array}{l}\text { Thickness } \\
(\mathrm{m})\end{array}$ & $\begin{array}{c}V_{s} \\
(\mathrm{~m} / \mathrm{s}) \\
\end{array}$ & $\begin{array}{l}\text { Initial modulus } \\
(\mathrm{kPa})\end{array}$ & Modulus reduction curves & Damping ratio curves \\
\hline Fill & 20.1 & 1.0 & 211 & $9.4 e 4$ & $\begin{array}{c}\text { Deep cohesionless }(0-6 \mathrm{~m}) \\
{[32]}\end{array}$ & $\begin{array}{c}\text { Deep cohesionless }(0-6 \mathrm{~m}) \\
{[32]}\end{array}$ \\
\hline SM-1 & 20.2 & 2.0 & 144 & $5.86 e 4$ & Sand average [27] & Sand average [27] \\
\hline SM-2 & 20.2 & 1.5 & 215 & $9.4 e 4$ & Sand lower [27] & Sand lower [27] \\
\hline GM & 20.1 & 15.0 & 312 & $1.97 e 5$ & $\begin{array}{c}\text { Deep cohesionless }(15-36 \mathrm{~m}) \\
{[32]}\end{array}$ & $\begin{array}{c}\text { Deep cohesionless }(15-36 \mathrm{~m}) \\
{[32]}\end{array}$ \\
\hline
\end{tabular}

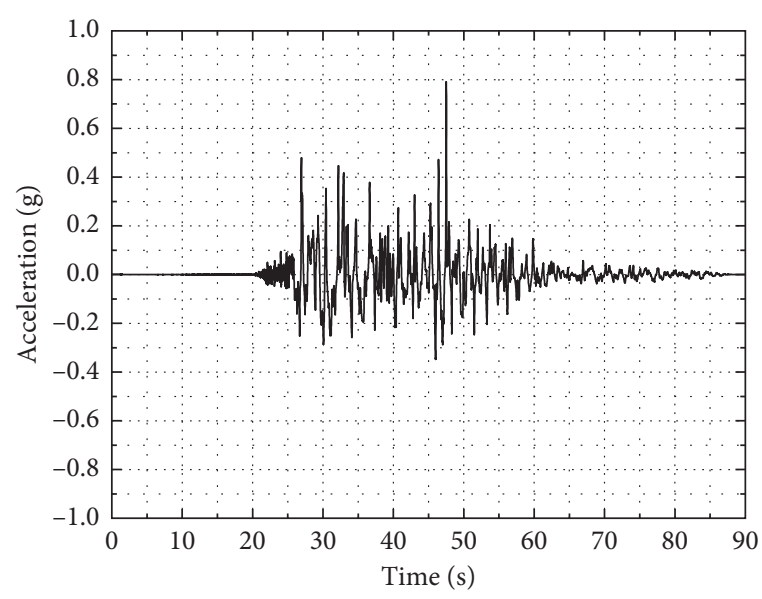

- TCU-650E

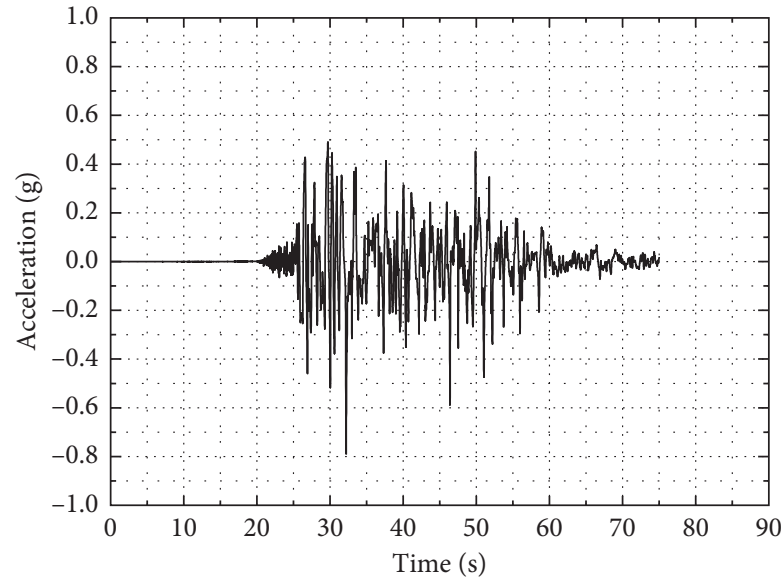

- TCU-650N

(a)

(b)

Figure 16: Input motions at the base of the soil profile. (a) TCU-650E and (b) TCU-650N.

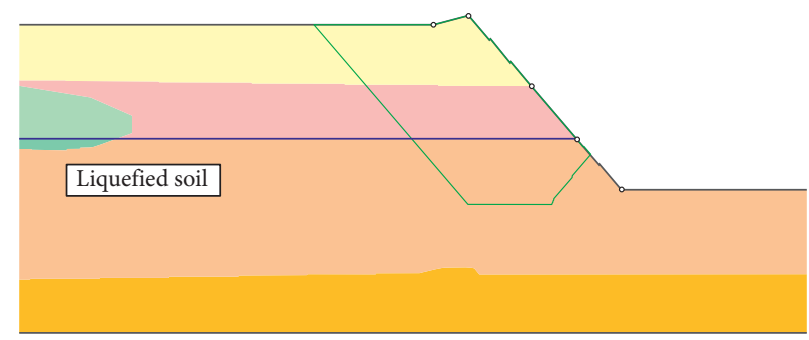

Figure 17: Postliquefaction yield acceleration of Wufeng site.

TABle 10: Newmark displacement analysis results by the simplified method (the reported displacement is reported as $1.62 \mathrm{~m}$ ).

\begin{tabular}{lcc}
\hline Motion name & Rigid block-normal $(\mathrm{m})$ & Rigid block-inverse $(\mathrm{m})$ \\
\hline TCU-650e & 1.70 & 1.81 \\
TCU-650n & 1.90 & 1.76 \\
\hline
\end{tabular}


Newmark displacement analysis. The same five case histories used in this paper were analyzed using the hybrid approach.

In addition, Rigorous Newmark sliding block analysis using the free-field ground motion recorded at the strong motion station or the ground surface motion deconvoluted from the equivalent linear analysis considering the triggering time of liquefaction and the postliquefaction yield acceleration was conducted to analyze the same case histories in this paper. Only the predicted results by the hybrid approach and rigorous Newmark sliding block method are presented herein. Note: the postliquefaction yield acceleration mentioned-above was calculated following the same procedures described in this paper: use the residual shear strength of the liquefied sand estimated by the correlation method by Idriss and Boulanger [24] residual shear strength relationship and conduct the limit equilibrium analysis.

The average values of the predicted lateral spreading and the reported lateral spreading for the five case histories are summarized in Table 11. To make a distinction between the different prediction methods, the average prediction by the simplified method in this paper (i.e., Newmark sliding block method using triggering time of liquefaction and the motions underneath the liquefiable soil from the one-dimensional effective stress analysis) is denoted as predicted displacement-1. The average prediction by the hybrid approach (i.e., Newmark sliding block method using triggering time of liquefaction and the motions underneath the liquefiable soil based upon the finite difference analysis) is denoted as predicted displacement-2. The average prediction by the rigorous Newmark sliding block analysis using the free-field ground motion recorded at the strong motion station or the ground surface motion deconvoluted from the equivalent linear analysis considering the triggering time of liquefaction is denoted as predicted displacement-3. By monitoring the crest of the free face when solely conducting the finite difference analysis using PM4sand constitutive model of liquefied sand for the same five case histories in this paper, the lateral spreading predicted by the finite difference analysis is denoted as predicted displacement- 4 and shown in Table 11.

The estimation of lateral spreading varies with the case histories. For the Wildlife site case, the prediction by the simplified method (i.e., predicted displacement-1) of $0.02 \mathrm{~m}$ is the smallest value comparing to the reported lateral spreading and the other three predictions. The simplified method (i.e., predicted displacement-1) predicts the smallest lateral spreading for the Moss landing site. By calculating the ratio of the predicted to reported displacement, the ratio of 0.61 indicates that the prediction error is the lowest though it underpredicts the lateral spreading. The prediction by the simplified method (predicted displacement-1) is equal to the reported displacement for the Northridge site. For the Port island case, the predictions by the four methods are smaller than the reported displacement. By calculating the ratio of the predicted to the reported displacement, the simplified method proposed in this paper yields a ratio of 0.5 , which is greater than that of the other three methods. For the Chi-Chi site, the predicted displacement-2, which is the displacement calculated by the hybrid approach, is the largest prediction among the four values and is 1.7 times the reported lateral spreading. The simplified method yields the ratio of the predicted to reported lateral spreading as 1.10 .

Calculate the ratio of the predicted lateral spreading to reported lateral spreading and then average the ratios of the five case histories for each prediction method to estimate the accuracy of the four methods. The average displacement ratio for the simplified method is 0.67 . For the rest of the four methods, the average displacement ratio of the hybrid approach is 2.79 , the average displacement ratio for the rigorous Newmark sliding block method is 1.27 , and the ratio for the finite difference analysis is 2.16. Comparing to the other three methods, of which the average ratio is greater than 1.0, the simplified method in this paper underestimates the lateral spreading in terms of the average displacement ratio; thus, a safety factor was suggested being considered when using the simplified method. More comparisons between the four methods are made based on the coefficients of determination. Based on the displacement ratios (i.e., the ratio of predicted lateral spreading to the reported lateral spreading) for each method, the RMSE (root mean square error), standard deviation, and CV (coefficient of variation) are calculated. In respect of the three coefficients of determination, the simplified method yields the lowest values, while the hybrid approach yields the greatest values among the four methods. The three values for the simplified method are $0.63,0.40$, and 0.60 , respectively. For the hybrid approach, the three values are $2.80,2.54$, and 0.91 , respectively. It is indicated that the simplified method is more capable of predicting the lateral spreading since higher values represent a greater degree of relative variability.

Some factors may contribute to the different predictions. Most importantly, there are some inherent limitations of the simplified method proposed in this paper. In the field, the yield acceleration will change due to the decrease of the inclination [42, 43] (downward movement of sliding mass) and the change of the geometry for the sliding mass [44] while the Newmark sliding block method assumes the sliding mass to be a perfectly rigid block, which slides at a constant yield acceleration. The rotation effects of the sliding mass are omitted since the simplified method is proposed based on the frame of the Newmark sliding block method, which would result in the uncertainty of the predicted displacement. The other factors include the uncertainties of the input parameters. The soil parameters such as water table depth, shear velocity, plasticity index of clay, fines content of sand, and SPT blow count of the liquefied soil are prone to uncertainty. The uncertainties of the hysteretic models of the dynamic curves used in the one-dimensional effective stress analysis and finite difference analysis are also affecting the soil response and further affect the accuracy of the lateral spreading. Furthermore, the input motions used in the analysis will also influence the accuracy of the lateral spreading prediction.

\section{Summary and Conclusions}

In this study, a simplified method was proposed to predict the liquefaction-induced lateral spreading. The simplified 
TABLe 11: Predicted lateral spreading and the reported displacement.

\begin{tabular}{lccccc}
\hline Case name & $\begin{array}{c}\text { Predicted } \\
\text { displacement-1 }(\mathrm{m})\end{array}$ & $\begin{array}{c}\text { Predicted } \\
\text { displacement-2 }(\mathrm{m})\end{array}$ & $\begin{array}{c}\text { Predicted } \\
\text { displacement-3 }(\mathrm{m})\end{array}$ & $\begin{array}{c}\text { Predicted } \\
\text { displacement-4 }(\mathrm{m})\end{array}$ & $\begin{array}{c}\text { Reported } \\
\text { displacement }(\mathrm{m})\end{array}$ \\
\hline $\begin{array}{l}\text { Wildlife site } \\
\text { Moss landing }\end{array}$ & 0.02 & 0.25 & 0.09 & 0.32 & 0.18 \\
site & 0.17 & 1.78 & 0.67 & 1.09 & 0.28 \\
Northridge site & 0.15 & 0.26 & 0.16 & 0.12 & 0.15 \\
Port island site & 1.42 & 0.21 & 0.77 & 1.11 & 2.80 \\
Chi-Chi site & 1.79 & 7.12 & 3.40 & 6.39 & 1.62 \\
\hline
\end{tabular}

method was developed on the basis of the Newmark sliding block method and took account of the postliquefaction yield acceleration and the motion beneath the liquefied soil started from the time of liquefaction triggering. D-mod 2000, which implemented the nonlinear stress-strain and pore water pressure generation model, was used in the study for calculating the triggering time of liquefaction and motions beneath the liquefied soil. To calculate the postliquefaction yield acceleration, the residual shear strength estimation method by Idriss and Boulanger [24] was used to estimate the residual shear strength of the liquefied soil, and the Morgenstern-Price method was applied to perform the limit equilibrium analysis.

To evaluate the accuracy of the proposed method, five case histories were reexamined and the comparison between the calculated lateral spreading with the actual displacement was made. The soil profile in each case was established from the documentations. In the effective stress analysis, the soil properties and the dynamic curves were estimated based upon the soil classification and the case-history documentation. The free-field motions or the downhole motions used for the effective stress analyses were selected in the NGAWest 2 database. In the limit equilibrium analysis, the twodimensional soil profile was developed based on the casehistory documentations.

Predictions of the simplified method, rigorous Newmark sliding block method, finite difference method, and Newmark sliding method taking account of the motion beneath the liquefied soil and triggering time of liquefaction calculated by finite difference analysis were compared in terms of lateral spreading for five well-documented case histories. It is indicated that the simplified method proposed in the paper gives a reasonable estimation of the lateral spreading. In the five case histories, the prediction by the simplified method was equal to the reported displacement for the Northridge site. The simplified method predicted smaller lateral spreading comparing to the reported displacement for the Wildlife site, Moss landing site, and Port island site, respectively. The simplified method overestimated the lateral spreading of the Chi-Chi site slightly greater than the observed displacement. By calculating the average displacement ratio, the simplified method underpredicted the lateral spreading. Comparing to the other three methods: the hybrid approach, the rigorous Newmark sliding block method, and finite difference analysis, a safety factor was suggested to be considered when using the simplified method.

To conclude, the effective stress analysis using the Modified Konder-Zelaso model requires only soil column investigation, and the input motion can be applied as an outcrop motion directly in the analysis. The one-dimensional effective stress analysis conducted by D-mod 2000 makes the simplified method more applicable in engineering practice compared to other methods. Nevertheless, the application of the simplified method has some limitations: the downward movement and the geometry change of the sliding mass will affect the yield acceleration; the variability of liquefiable soil below the ground surface will induce the uncertainty of the prediction; the calculated lateral spreading may be overestimated or underestimated due to the lack of site-specific motion for some situations; and sliding surface in the limit equilibrium analysis will change during the shaking in reality, which will affect the postliquefaction yield acceleration and calculated the lateral spreading. Due to the limited field observations, the accuracy of the simplified method needs to be validated with more case histories.

\section{Data Availability}

The data used to support the results of the study are included within the paper.

\section{Conflicts of Interest}

The authors declare that there are no conflicts of interest regarding the publication of this paper.

\section{Acknowledgments}

The authors would also like to thank CSC (China Scholarship Council) for its financial support and guidance from Professor Kavazanjian at Arizona State University. This work was supported by the China Scholarship Council (Grant no. 201407000019).

\section{References}

[1] M. Hamada, S. Yasuda, R. Isoyama, and K. Emoto, "Study on liquefaction-induced permanent ground displacements and earthquake damage," Doboku Gakkai Ronbunshu, vol. 1986, no. 376, pp. 221-229, 1986.

[2] J. P. Bardet, N. Mace, and T. Tobita, Liquefaction-induced Ground Deformation and Failure, University of Southern California, Los Angeles, CA, USA, 1999.

[3] S. F. Bartlett and T. L. Youd, "Empirical analysis of horizontal ground displacement generated by liquefaction-induced lateral spreads," National Center for Earthquake Engineering Research, Brigham Young University, Buffalo, NY, USA, 1992. 
[4] S. F. Bartlett and T. L. Youd, "Empirical prediction of liquefaction-induced lateral spread," Journal of Geotechnical Engineering, vol. 121, no. 4, pp. 316-329, 1995.

[5] A. F. Rauch and J. R. Martin III III, "EPOLLS model for predicting average displacements on lateral spreads," Journal of Geotechnical and Geoenvironmental Engineering, vol. 126, no. 4, pp. 360-371, 2000.

[6] T. L. Youd, C. M. Hansen, and S. F. Bartlett, "Revised multilinear regression equations for prediction of lateral spread displacement," Journal of Geotechnical and Geoenvironmental Engineering, vol. 128, no. 12, pp. 1007-1017, 2002.

[7] K. W. Franke and S. L. Kramer, "Procedure for the empirical evaluation of lateral spread displacement hazard curves," Journal of Geotechnical and Geoenvironmental Engineering, vol. 140, no. 1, pp. 110-120, 2014.

[8] A. A. Javadi, M. Rezania, and M. M. Nezhad, "Evaluation of liquefaction induced lateral displacements using genetic programming," Computers and Geotechnics, vol. 33, no. 4-5, pp. 222-233, 2006.

[9] W. D. L. Finn, J. Dowling, and C. E. Ventura, "Evaluating liquefaction potential and lateral spreading in a probabilistic ground motion environment," Soil Dynamics and Earthquake Engineering, vol. 91, pp. 202-208, 2016.

[10] L. T. Ekstrom and K. W. Franke, "Simplified procedure for the performance-based prediction of lateral spread displacements," Journal of Geotechnology and Geoenvironmental Eng, vol. 142, no. 7, Article ID 04016028, 2016.

[11] A. VALSAMIS, G. Bouckovalas, and V. Dimitriadi, "Numerical evaluation of lateral spreading displacements in layered soils," in Proceedings of the 4th 4th International Conference on Earthquake Geotechnical, pp. 25-28, Thessaloniki, Greece, June 2007.

[12] M. Seid-Karbasi and P. M. Byrne, "Seismic liquefaction, lateral spreading, and flow slides: a numerical investigation into void redistribution," Canadian Geotechnical Journal, vol. 44, no. 7, pp. 873-890, 2007.

[13] A.-W. Elgamal and Z. Yang, "Numerical modeling of liquefaction-induced lateral spreading," in Proceedings of the Twelfth World Conference on Earthquake Engineering, Auckland, New Zealand, 2000.

[14] R. W. Boulanger and K. Ziotopoulou, "PM4Sand (Version 2): a sand plasticity model for earthquake engineering applications, Center Geotech. Modeling," University of California, Davis, CA, USA, 2012.

[15] R. W. Boulanger and K. Ziotopoulou, "PM4SAND (Version 3): a sand plasticity model for earthquake engineering applications Center Geotech. Modeling," University of California, Davis, CA, USA, 2015.

[16] N. M. Newmark, "Effects of earthquakes on dams and embankments," Géotechnique, vol. 15, no. 2, pp. 139-160, 1965.

[17] I. M. Idriss and J. I. Sun, "SHAKE91: A computer program for conducting equivalent linear seismic response analyses of horizontally layered soil deposits," Civil and Environmental Engineering, University of California, Davis, CA, USA, 1992.

[18] M. K. W. Lee and W. D. L. Finn, DESRA-2: Dynamic Effective Stress Response Analysis of Soil Deposits with Energy Transmitting Boundary Including Assessment of Liquefaction Potential, University of British Columbia, Vancouver, Canada, 1978.

[19] L. L. C. GeoMotions, D.-M. O. D. 2000, A Computer Program for Seismic Response Analysis of Horizontally Layered Soil Deposit, Earthfill Dams, and Solid Waste Landfills, Lacey, Washington, DC, 2007.
[20] N. Matasović and M. Vucetic, "Cyclic characterization of liquefiable sands," Journal of Geotechnical Engineering, vol. 119, no. 11, pp. 1805-1822, 1993.

[21] R. L. Konder and J. S. Zelasko, "A hyperbolic stress-strain formulation for sands," in Proceedings of the Second Panamerican Conference on Soil Mechanics and Foundation Engineering, pp. 289-324, Guadalajara, Mexico, 1963.

[22] E. Seyhan, J. P. Stewart, T. D. Ancheta, R. B. Darragh, and R. W. Graves, "NGA-West2 site database," Earthquake Spectra, vol. 30, no. 3, pp. 1007-1024, 2014.

[23] N. R. Morgenstern and V. E. Price, "The analysis of the stability of general slip surfaces," Géotechnique, vol. 15, no. 1, pp. 79-93, 1965.

[24] I. M. Idriss and R. W. Boulanger, "2nd Ishihara Lecture: SPTand CPT-based relationships for the residual shear strength of liquefied soils," Soil Dynamics and Earthquake Engineering, vol. 68, pp. 57-68, 2015.

[25] T. L. Holzer, T. C. Hanks, and T. L. Youd, "Dynamics of liquefaction during the 1987 superstition Hills, California, earthquake," Science, vol. 244, no. 4900, pp. 56-59, 1989.

[26] J.-Y. Ching and S. D. Glaser, "1D time-domain solution for seismic ground motion prediction," Journal of Geotechnical and Geoenvironmental Engineering, vol. 127, no. 1, pp. 36-47, 2001.

[27] H. B. Seed and I. M. Idriss, "Soil moduli and damping factors for dynamic response analyses," University of California, Berkley, CA, USA, 1970.

[28] M. Vucetic and R. Dobry, "Effect of soil plasticity on cyclic response," Journal of Geotechnical Engineering, vol. 117, no. 1, pp. 89-107, 2001.

[29] A. J. Makdisi, "The applicability of sliding block analyses for the prediction of lateral spreading displacements," MS thesis, University of Washington, Seattle, WA, USA, 2016.

[30] R. W. Boulanger, L. H. Mejia, and I. M. Idriss, "Liquefaction at Moss landing during loma Prieta earthquake," Journal of Geotechnical and Geoenvironmental Engineering, vol. 123, no. 5, pp. $453-467$.

[31] M. B. Darendeli, Development of a New Family of Normalized Modulus Reduction and Material Damping Curves, The University of Texas at Austin, Austin, TX, USA, 2001.

[32] Electric Power Research Institute Guideline, Guidelines for Site Specific Ground Motions, Electric Power Research Institute Guideline, Washington, DC, 1993.

[33] B. Chiou, R. Darragh, N. Gregor, and W. Silva, "NGA project strong-motion database," Earthquake Spectra, vol. 24, no. 1, pp. 23-44, 2008.

[34] T. L. Holzer, M. J. Bennett, D. J. Ponti, and J. C. Tinsley, "Liquefaction and soil failure during 1994 Northridge earthquake," Journal of Geotechnical and Geoenvironmental Engineering, vol. 125, no. 6, pp. 438-452, 1999.

[35] S. P. G. Madabhushi, "Strong motion at port island during the kobe earthquake," Technical Report, Cambridge University, Cambridge, UK, 1995.

[36] D. S. Yang, "Deformation-based seismic design models for waterfront structures," Ph.D. Dissertation, Oregon State University, Eugene, OR, USA, 1999.

[37] H. Inagaki, S. Iai, T. Sugano, H. Yamazaki, and T. Inatomi, "Performance of caisson type quay walls at Kobe port," Soils and Foundations, vol. 36, pp. 119-136, 1996.

[38] H. B. Seed, R. T. Wong, I. M. Idriss, and K. Tokimatsu, "Moduli and damping factors for dynamic analyses of cohesionless soils," Journal of Geotechnical Engineering, vol. 112, no. 11, pp. 1016-1032, 1986. 
[39] I. M. Idriss and R. W. Boulanger, "SPT-based liquefaction triggering procedures," Center Geotech. Modeling," University of California at Davis, Davis, CA, USA, 2010.

[40] D. B. Chu, J. P. Stewart, T. L. Youd, and B. L. Chu, "Liquefaction-induced lateral spreading in near-fault regions during the 1999 Chi-Chi, Taiwan earthquake," Journal of Geotechnical and Geoenvironmental Engineering, vol. 132, no. 12, pp. 1549-1565, 2006.

[41] Itasca, Fast Lagrangian Analysis of Continua, Ver. 7.0, Itasca Consulting Group, Inc, Minneapolis, MN, USA, 2011.

[42] Y. Jafarian and A. Lashgari, "Simplified procedure for coupled seismic sliding movement of slopes using displacement-based critical acceleration," International Journal of Geomechanics, vol. 16, no. 4, Article ID 04015101, 2016.

[43] C. A. Stamatopoulos, "Sliding system predicting large permanent co-seismic movements of slopes," Earthquake Engineering \& Structural Dynamics, vol. 25, no. 10, pp. 1075-1093, 1996.

[44] C. A. Stamatopoulos, C. Mavromihalis, and S. Sarma, "Correction for geometry changes during motion of slidingblock seismic displacement," Journal of Geotechnical and Geoenvironmental Engineering, vol. 137, no. 10, pp. 926-938, 2011. 